\title{
Sprawozdanie z udziału \\ w Stage technique international d'archives \\ we Francji, Paryż, Lyon 25 III-26 IV 2019 r.
}

Już od wielu lat archiwa państwowe w Polsce otrzymują z Francji zaproszenie do udziału polskich archiwistów w Stage technique international d'archives, który organizowany jest we Francji od 1951 roku. Wielu polskich archiwistów miało możliwość wziąć udział w szkoleniach, które podejmują wszelkie zagadnienia związane z archiwistyką we Francji. Dzięki rekomendacji udzielonej przez dyrektora Archiwum Państwowego w Lublinie oraz Naczelną Dyrekcję Archiwów Państwowych w Warszawie, a zwłaszcza dzięki przychylności pracowników Ambasady Francuskiej w Warszawie, zostałam zakwalifikowana do udziału w stażu. Do tegorocznej edycji zakwalifikowano 37 uczestników z 27 krajów spośród 375 zgłoszonych kandydatur - to naprawdę ogromne wyróżnienie dla kolejnego pracownika Archiwum Państwowego w Lublinie ${ }^{1}$.

Celem tegorocznej edycji stażu było zapoznanie uczestników z organizacją i funkcjonowaniem archiwów we Francji, wizyty studyjne, warsztaty tematyczne, wymiana doświadczeń - prezentacje doświadczeń archiwów różnych krajów, realizowane poprzez wystąpienia stażystów, prezentacje i dyskusje z naciskiem na zarządzanie dokumentacją elektroniczną oraz kopiami cyfrowymi, uzyskanymi w procesie digitalizacji materiałów archiwalnych w tradycyjnej postaci.

Udział w stażu poprzedził kurs e-learningowy SPOC Archives - course en ligne przygotowany we współpracy z Uniwersytetem Paryskim ${ }^{2}$ i ekspertami z Archives nationales Pierrefitte-sur-Seine ${ }^{3}$ i École nationale des chartes ${ }^{4}$. Kurs trwał od 4 stycznia do 26 kwietnia i obejmował 7 modułów tematycznych z zadaniami sprawdzającymi i oceną na zakończenie każdego z modułów (uczestnicy otrzymali także certyfikaty odbycia kursu). Dzięki systematycznym szkoleniom każdy

1 Zob. K. Szejgiec, Archiwistyka francuska wobec wyzwań XXI wieku (Stage technique international d'archives 20 maja - 30 czerwca 2016, Paryż), „Studia Archiwalne”, t. 4, 2016, s. 281-285.

$2<$ https://www.univ-paris8.fr/>, [dostęp: 29.04.2019].

$3<$ http://www.archives-nationales.culture.gouv.fr/site-de-pierrefitte-sur-seine/>, [dostęp: 29.04.2019].

$4<$ http://www.chartes.psl.eu/>, [dostęp: 29.04.2019]. 
uczestnik miał możliwość zapoznania się ze stosowaną terminologią, metodyką pracy $\mathrm{w}$ archiwach francuskich, a także $\mathrm{z}$ obowiązującymi przepisami prawa i uporządkowania podstawowej wiedzy teoretycznej w tym zakresie w dogodnym dla siebie czasie.

Stage technique international d'archives podzielony został także na kilka modułów tematycznych, z których każdy odpowiadał różnym aspektom pracy francuskiego archiwisty.

Wprowadzenie (Introduction) - podczas pierwszych dwóch dni przedstawiono nam założenia i program stażu. Był to również czas poświęcony autoprezentacji i integracji uczestników. Zapoznaliśmy się także z funkcjonalnościami Portail International Archivistique Francophone, PIAF ${ }^{5}$ platformy, która od 2005 roku służy archiwistom krajów frankofońskich do komunikacji, wymiany informacji, szkoleń i dzielenia się doświadczeniami oraz metodami pracy.

Podczas następnych 3 dni stażu, poświęconych misji archiwów i ich miejscu w strukturze społecznej (Maîtriser les missions d'un service d'archives et l'ancrer dans son environnement), odbyliśmy wizyty w Archives nationales Pierrefitte-sur-Seine, gdzie zapoznaliśmy się z misją archiwum. Podczas pracy $\mathrm{w}$ grupach stażyści odbyli szereg równoległych wizyt studyjnych $\mathrm{w}$ różnych instytucjach, do których zostali oddelegowani w celu zapoznania się z różnorodnymi formami organizacji archiwów urzędów, instytucji. Zdobyte informacje i doświadczenia prezentowane były na popołudniowej sesji wspólnej. Znalazłam się w grupie, która zapoznała się z systemem udostępniania materiałów archiwalnych grupy Société nationale des chemins de fer français, SNCF - państwowego przewoźnika kolejowego, który jest jednym z największych przedsiębiorstw we Francji. Zostaliśmy zapoznani z systemami: Services Archives Documentation de la SNCF, SARDO ${ }^{6}$ - to system, za pośrednictwem którego udostępnia się materiały archiwalne on-line oraz ADELE i Ged'iT - systemy służące do zarządzania dokumentacją elektroniczną oraz dokumentacją, która została przeniesiona $\mathrm{z}$ wersji papierowej do wersji elektronicznej (kopiami cyfrowymi).

Główne narzędzia w zarządzaniu serwisami archiwalnymi (Elaborer des outils strategiques de pilotage d'un service d'archives) to zagadnienie, na które poświęciliśmy kolejne dwa dni stażu. Podczas wizyty w Archiwum Dyplomatycznym (Archives diplomatiques, La Courneuve) ${ }^{7}$ mieliśmy czas na zapoznanie

\footnotetext{
<https://www.piaf-archives.org >, [dostęp: 29.04.2019].

<https://www.openarchives.sncf.com>, [dostęp: 29.04.2019].

$<$ https://www.diplomatie.gouv.fr/fr/archives-diplomatiques/>, [dostęp: 29.04.2019].
} 
się z historią i strukturą archiwum oraz zasadami udostępniania materiałów archiwalnych, a także stroną i katalogiem biblioteki archiwalnej, której rangę i rolę mocno podkreślano podczas prezentacji instytucji. Stażyści zostali podzieleni na grupy, według zadeklarowanych w zgłoszeniu do stażu zainteresowań. Znalazłam się w grupie, która miała możliwość zapoznać się z procesem przygotowywania wystaw na przykładzie doświadczeń pracowników Archiwum Dyplomatycznego. Ponadto zostaliśmy zapoznani z założeniami i celami Programu Naukowego, Edukacyjnego i Kulturalnego (Programme Scientifique Educatif et Culturel, PSCE), który został zrealizowany w latach 2013-2016, a który podejmował tematykę ścisłej współpracy Archiwum Narodowego z instytucjami i środowiskami naukowymi. Jego celem było przygotowanie odpowiedniej oferty edukacyjnej archiwów jako odpowiedź na zapotrzebowania określonych grup odbiorców. W ramach modułu zwiedziliśmy także budynek archiwum, tj. czytelnię i bibliotekę, czytelnię mikrofilmów, pracownię konserwacji, digitalizacji i opracowania materiałów archiwalnych oraz magazyny, w tym magazyn kartografii.

Budowanie i motywacja zespołu (Constituer et motive equipe) to jednodniowe zajęcia $\mathrm{z}$ trenerem interpersonalnym, podczas których odbyliśmy ćwiczenia praktyczne i teoretyczne $\mathrm{z}$ zakresu zarządzania zasobami ludzkimi na przykładzie doświadczeń pracowników archiwów. Integracja zespołu, współpraca, motywacja - to główne zagadnienia, które zostały w tym module poruszone w sposób innowacyjny. Podczas praktycznych ćwiczeń grupa zbierała doświadczenia i odnajdywała odpowiedź na pytanie „Jak wspólnie dokonać niemożliwego?” w kontekście pracy zespołowej.

Odpowiedzialność i ochrona przed ryzykiem (Responsabilite et preservation des risques). Dzięki doświadczeniu profesjonalnej kadry pracowników Archiwum Narodowego w czasie dwudniowego modułu poznawaliśmy zasady zabezpieczania materiałów archiwalnych. Były to praktyczne zajęcia z konserwacji materiałów archiwalnych z prezentacją materiałów i narzędzi używanych podczas restaurowania materiałów archiwalnych, ćwiczeniami praktycznymi (tworzenie obwolut i pudeł zabezpieczających), prezentacją atestowanych materiałów (papieru, tektur i tworzyw sztucznych) używanych do zabezpieczenia technicznego materiałów archiwalnych. W trakcie tych zajęć omówiliśmy także czynniki ryzyka i możliwe zagrożenia dla materiałów archiwalnych - było to niezwykle ciekawe doświadczenie, ponieważ uczestnicy stażu pochodzili z różnych kontynentów i krajów, wobec czego omawiane w grupach czynniki ryzyka były bardzo różnorodne, a dyskusje bardzo inspirujące. W zajęciach grupowych 
przygotowywaliśmy także scenariusze zapobiegania możliwym zagrożeniom lub scenariusze niwelowania strat po wystąpieniu czynników ryzyka - moja grupa miała za zadanie omówić przykład poprawienia warunków przechowywania materiałów archiwalnych $\mathrm{w}$ piwnicy, bez odpowiedniej wentylacji, z wysokimi wahaniami temperatury i wilgotności w ciągu roku, z czynnikiem ryzyka - skorodowanymi rurami kanalizacyjnymi.

Ponadto w ramach terenowych zajęć praktycznych zwiedzaliśmy budynek Archiwum Narodowego (Hôtel de Soubise, Paryż), zwracając baczną uwagę na systemy przeciwpożarowe, oznaczenia budynku niezbędne przy ewakuacji pracowników i materiałów archiwalnych, wyposażenie techniczne magazynów i pomieszczeń, które mają na celu ochronę personelu i zasobu archiwalnego. Poznaliśmy również procedury i plany ewakuacji archiwum na wypadek pożaru, gdzie szczególną uwagę zwróciliśmy na oznakowanie magazynów i regałów, w których umieszczone są najcenniejsze materiały archiwalne oznaczone najwyższym priorytetem ewakuacji.

Tworzenie zasobu (Maîtriser la collecte) to najbardziej inspirujący z modułów, w którym dzięki zaangażowaniu i profesjonalizmowi archiwistów z École nationale des chartes oraz grupy La Poste (francuskiej instytucji państwowej świadczącej usługi pocztowe) zapoznaliśmy się z metodami pracy zarządzania dokumentacją z punktu widzenia aktotwórcy oraz archiwisty zakładowego. W szerokim kontekście zostało omówione zagadnienie records management, czyli zarządzania dokumentacją od momentu jej wytworzenia poprzez identyfikowanie, klasyfikowanie, przechowywanie, zabezpieczanie, niszczenie (brakowanie) lub trwałe zachowanie dokumentów, czy informacji wytworzonych $\mathrm{w}$ formie elektronicznej. Podczas rozbudowanych ćwiczeń praktycznych pracowaliśmy w grupach nad różnymi zagadnieniami, konstruowaliśmy przykładowy workflow dla hipotetycznego urzędu $\mathrm{z}$ uwzględnieniem procesu archiwizacji dokumentów wytwarzanych w ramach jego funkcjonowania. Budowaliśmy scenariusze postępowania $\mathrm{z}$ dokumentacją tradycyjną - papierową, „mieszaną" i elektroniczną. Omówiony został także proces archiwizacji w oparciu o możliwości praktyczne systemu archiwizacji SAE (Systeme d'archivage electronique).

W ramach tematu przewodniego modułu odwiedziliśmy także utworzony w 2005 r. Service historique de la Défense, SHD $^{8}$ z siedzibą w Château de Vincennes, który został nam zaprezentowany jako przykład centrum historycznego i archiwum wojskowego, które posiada bogaty zasób archiwalny (450 km akt

$8<$ <ttps://www.servicehistorique.sga.defense.gouv.fr>, [dostęp: 29.04.2019]. 
od XVII w.), jak również wyspecjalizowaną bibliotekę (prawie milion książek o tematyce historycznej, militarnej). Poznaliśmy strukturę SHD, zasady udostępniania materiałów archiwalnych, zwiedziliśmy także imponującą czytelnię im. Ludwika XIV. Zostały również zaprezentowane systemy i aplikacje wykorzystywane w archiwach do zarządzania dokumentacją elektroniczną i zasobami zdigitalizowanymi, tj.: ADAMANT - system opracowany wspólnie przez Ministerstwo Kultury i Archiwum Narodowe (Ministère de la Culture, Archives nationales), ARCHIPEL - system opracowany na potrzeby Ministerstwa Sił Zbrojnych (Archivages Physice et Electronique, Ministère des Armées), VITAM - pierwsza aplikacja do zarządzania dokumentacją zarówno w postaci tradycyjnej, papierowej, jak i dokumentacji elektronicznej.

Miłym akcentem w rozbudowanym i bogatym programie stażu była wycieczka programowa do Lyonu (Voyage d'etudes).

Pierwszego dnia zwiedziliśmy budynek Archiwum departamentalnego i metropolitalnego w Lyonie (Archives du département du Rhône et de la Métropole de Lyon $)^{9}$, które mieści się w nowoczesnym i specjalnie zaprojektowanym na potrzeby archiwum budynku z imponującą przestrzenią przeznaczoną na ekspozycje, przestronną czytelnią i salami konferencyjno-edukacyjnymi. Specjalnie dla nas zostały przeprowadzone tematyczne warsztaty archiwalne z prezentacją oryginalnych, bardzo ciekawych dokumentów z zakresu rolnictwa, sądownictwa, służby zdrowia i ewidencji ludności - w tym najstarsze zielniki, jedne z pierwszych zdjęć rentgenowskich wykonanych we Francji, teczki pacjentów szpitala psychiatrycznego z niesamowitymi rysunkami i zapiskami osób umysłowo chorych, czy dokumenty i muzealia dotyczące działalności Czerwonego Krzyża, akta notarialne oraz sądowe, które są w tym archiwum gromadzone i przechowywane.

Drugiego dnia zaś gościliśmy w Archiwum miejskim miasta Lyon (Archives municipales Lyon $)^{10}$, gdzie również zapoznaliśmy się z jego strukturą organizacyjną, zasadami gromadzenia materiałów archiwalnych - archiwum to przechowuje m.in. dokumenty wytworzone na tym terenie przed 1790 r., archiwum miejskie po 1790 r., a także akta szpitali czy szkół. Tutaj mieliśmy możliwość zwiedzenia bardzo dużej, imponującej pod względem wizualnym i audiowizualnym (projekcja reportaży, wywiadów, ścieżka dźwiękowa), wystawy Kamień $i$ duch. Wystawa fotografii obiektów sakralnych miasta Lyon, których autorem

$9<$ http://www.archives.rhone.fr/>, [dostęp: 29.04.2019].

$10<$ http://www.archives-lyon.fr/archives/>, [dostęp: 29.04.2019]. 
był Gille Framinet, uzupełniona projektami architektonicznymi, technicznymi, rycinami i fotografiami z zasobu archiwalnego cieszyła się ogromnym zainteresowaniem i uznaniem ze strony uczestników stażu.

Tego dnia mieliśmy możliwość zapoznania się z procesem przygotowania wystaw stałych i czasowych, z podkreśleniem współpracy na tym polu z historykami (kontekst historyczny wystawy, komentarz merytoryczny, dobór dokumentów), architektami (kontekst rozmieszczenia wystawy w przestrzeni budynku lub miasta), scenografa (w kontekście aranżacji wystawy) oraz grafika komputerowego (w kontekście uzupełnienia wystaw w obiekty multimedialne, prezentacje wirtualne), czy też znawcę alfabetu Braille’a (który opatruje wszystkie obiekty i opisy w podpisy dostosowane do potrzeb osób niewidomych).

Zostaliśmy także zapoznani z pionierskim i innowacyjnym projektem rekonstrukcji miasta w formacie 3D - Miasto przemysłowe, który został zainspirowany i oparty na materiałach archiwalnych (plany techniczne, fotografie, rzuty budynków, etc.), zrealizowany przez grupę studentów przy użyciu specjalistycznych programów ${ }^{11}$, którzy zrekonstruowali od podstaw budynki na podstawie materiałów archiwalnych. W efekcie można zwiedzać wirtualnie takie budynki także od wewnątrz.

Dodatkową atrakcją podczas pobytu w Lyonie było zwiedzenie Muzeum Historii Lyonu oraz Muzeum Lalek (Musée d'Historie du Lyon, Musée Gadagne) ${ }^{12}$.

Kolejny moduł został poświęcony metodom opracowania zespołów (Savoir comparer les methodes de traitement des fonds). W trakcie trzydniowych zajęć praktycznych w Archives Nationales omawialiśmy tematykę klasyfikacji i opracowania materiałów archiwalnych, archiwizacji kolekcji i prywatnych archiwów w oparciu o obowiązujące przepisy. W ramach tego modułu odbyliśmy także krótkie kursy kodowania opisów archiwalnych ${ }^{13} \mathrm{w}$ oparciu o normy Międzynarodowego standardu opisu archiwalnego, (ISAAD G), Międzynarodowego standardu archiwalnych haset wzorcowych ciał zbiorowych, osób i rodzin (ISAAR-CPF), Międzynarodowego standardu opisu funkcji (ISDF) oraz Międzynarodowego standardu opisu instytucji z zasobem archiwalnym (ISDIAH).

W ramach modułu został nam także zaprezentowany bardzo ciekawy projekt digitalizacji materiałów archiwalnych połączony $\mathrm{z}$ ich indeksowaniem -

\footnotetext{
${ }^{11}$ Autorzy w prezentacji wymienili programy m.in. AutoCad, Viral, Photoshop.

$12<$ http://www.gadagne.musees.lyon.fr/>, [dostęp: 29.04.2019].

13 Przy użyciu języków kodowania XML, HTML i programów EAD/DTD (Document Type Definition), AtoM (Acces to Memory).
} 
Projet participatif Ponts et Chaussées (Projekt współpracy Mosty i Drogi) ${ }^{14}$, jako jeden z przykładów współpracy w zakresie transkrypcji, adnotacji i indeksacji materiałów archiwalnych prowadzony przez Archiwum Narodowe. Został on zrealizowany wspólnie przez kilka instytucji: Archives nationales, Ministère de l'Environnement, de l'Energie et de la Mer, École des Ponts, Rails \& Histoire Association pour l'histoire des chemin des fer. Projekt jest tym bardziej interesujący, że indeksowaniem zdigitalizowanych rejestrów wytworzonych przez Conseil général des ponts et chaussées - Radę Generalną Dróg i Mostów (zespół przechowywany w zasobie Archiwum Narodowego) ${ }^{15}$ zajmują się wolontariusze, studenci pasjonaci historii, miłośnicy kolejnictwa.

$\mathrm{Z}$ kolei podczas wizyty w Bibliothèque nationale de France, $\mathrm{BnF}^{16}$ mieliśmy możliwość zapoznania się $\mathrm{z}$ doświadczeniami w zakresie digitalizacji zbiorów bibliotecznych. Zwiedziliśmy pracownię digitalizacji oraz zapoznaliśmy się z portalem Gallica ${ }^{17}$, gdzie udostępniane są on-line wszystkie zdigitalizowane zbiory biblioteczne.

Ostatni moduł był polem do dyskusji o miejscu i roli archiwisty w społeczeństwie. (Comprendre la rôle de l'archiviste dans la societe d'ajourd'hui). Tego dnia dyskutowaliśmy o różnicach w przepisach prawnych, dotyczących udostępniania materiałów archiwalnych, ochronie danych osobowych i prawie autorskim, także w kontekście dyrektywy 2003/98/WE z 2013, którą Polska wdrożyła do prawa polskiego w lutym 2016 roku.

$\mathrm{W}$ ramach tego modułu przedstawiłam swoją prezentację pt. Amuser et apprendre - photoblog Galeria Jezuicka 13 na temat doświadczeń Archiwum Państwowego w Lublinie w zakresie popularyzacji materiałów archiwalnych w formie fotobloga. Idea Galerii bardzo spodobała się uczestnikom stażu, choć dużą trudnością było przetłumaczenie opisów, które są zabawne w zasadzie tylko dla polskiego odbiorcy. Prezentacja wpisała się tematycznie także w panel dyskusyjny o roli social mediów jako narzędzia do komunikacji z użytkownikami, klientami archiwów.

W ramach modułu zostały przedstawione nam również inicjatywy podejmowane przez archiwa i środowiska związane $\mathrm{z}$ archiwami m.in. - Hackaton ${ }^{18}$

$14<$ https://archivnat.hypotheses.org/1466>, [dostęp: 29.04.2019].

15 Zespół numer F/14/17791 <https://www.siv.archives-nationales.culture.gouv.fr/siv/IR/ FRAN_IR_057838>, [dostęp: 29.04.2019].

${ }_{16}$ https://www.bnf.fr/fr, [dostęp: 29.04.2019.]

$17<$ https://www.gallica.bnf.fr>, [dostęp: 29.04.2019] - odpowiednik polskiego serwisu Biblioteki Narodowej polona.pl

$18<$ https://www.hackathon-archives-nationales.org/>, [dostęp: 29.04.2019]. 
(z ang. Hack-a-thon), które można zdefiniować jako warsztaty metod pracy powiązane z nowymi technologiami, dzięki którym uczestnicy wspólnie projektują i realizują internetowe i informatyczne przedsięwzięcia dla określonego celu - o ubiegłorocznej edycji Hackatonu w Archives nationales opowiadali jego organizatorzy.

Bardzo ciekawa prezentacja dotyczyła niedawno uruchomionego portalu FranceArchives ${ }^{19}$, który skupia archiwa publiczne, znajdujące się na terenie całego kraju, ułatwiając zarówno dostęp do ich zasobów i poruszanie się po udostępnionych on-line inwentarzach i przewodnikach, ale przede wszystkim zawiera sekcję zawodową, skierowaną do archiwistów, którzy mają dostęp do szerokiego kompendium wiedzy: przepisów prawnych, zarządzeń, wzorów formularzy, katalogu dobrych praktyk, literatury fachowej i bibliografii, etc. Zaletą portalu jest niewątpliwie to, że niezbędne materiały i narzędzia dostępne są w jednym miej$\mathrm{scu}$, pogrupowane w tematyczne moduły, odpowiadają procesom zachodzącym $\mathrm{w}$ postępowaniu $\mathrm{z}$ dokumentacją od momentu jej wytworzenia do momentu jej wybrakowania lub przekazania do archiwum narodowego lub departamentalnego, czy miejskiego.

Jako przykład ogromnego przedsięwzięcia na polu współpracy w indeksowaniu materiałów archiwalnych został zaprezentowany projekt Grand Mémorial $^{20}$. Użytkownicy Internetu mogą uczestniczyć w indeksowaniu materiałów archiwalnych - po zarejestrowaniu się otrzymują dostęp do kopii cyfrowych kart wojskowych żołnierzy i kombatantów I wojny światowej, przyczyniając się w ten sposób do upamiętnienia żołnierzy Wielkiej Wojny. Dzięki ogromnemu wsparciu obywateli, głównie genealogów, powstaje ogromna baza danych, dostępna dla wszystkich zainteresowanych. Baza tworzona poprzez indeksowanie rejestrów i gromadzone w Grand Mémorial opisy pozwala nie tylko na znalezienie informacji dotyczących konkretnego żołnierza, ale także na przeprowadzenie przekrojowych badań, dotyczących dat urodzenia, miejsc urodzenia i zamieszkania w czasie spisu powszechnego, poziomu wykształcenia, zawodu, klasy, etc. W sumie na zindeksowanie oczekuje 8,5 miliona opisów(!) - bez wsparcia ze strony środowisk genealogów i wolontariuszy projekt nie miałby szans powodzenia.

Tego dnia miała także miejsce uroczystość zamknięcia stażu, wręczenie dyplomów, które odbyło się w Ministerstwie Kultury w obecności wszystkich

19 <https://www.francearchives.fr/>, [dostęp: 29.04.2019] częściowo odpowiada idei i formie www.szukajwarchiwach.gov.pl

${ }^{20}<$ http://www.culture.fr/Genealogie/Grand-Memorial>, [dostęp 29.04.2019]. 
osób prowadzących zajęcia podczas stażu, a także zaproszonych dyplomatów (konsulów, ambasadorów) z krajów, z których pochodzili uczestnicy stażu. Na uroczystość ze strony polskiej został zaproszony przedstawiciel Stałego Przedstawicielstwa RP przy UNESCO, jednak ze względu na ważne obowiązki służbowe reprezentant tej instytucji nie mógł pojawić się na wręczeniu dyplomów.

Podsumowanie (Bilan du stage) odbyło się podczas ostatniego dnia stażu. Uczestnicy wypełnili obszerne ankiety ewaluacyjne. Koordynatorzy stażu: Jean Pierre Defrance oraz Sonia Salazar-Zea byli także moderatorami dyskusji o oczekiwaniach i trudnościach, z jakimi zetknęli się uczestnicy stażu, ale przede wszystkim o kierunkach rozwoju i przyszłym kształcie programu stażu. Stażyści w zasadzie jednogłośnie stwierdzili, że program był zbyt intensywny i bogaty w informacje. Jednakże za mała ilość czasu na zajęcia praktycznie nie do końca pozwoliła w pełni skorzystać z osiągnięć francuskiej archiwistyki na tym polu - stąd pojawiły się postulaty o wydłużenie czasu stażu i zwiększenie liczby zajęć praktycznych (zwłaszcza z zakresu kodowania opisów archiwalnych).

W trakcie 5 tygodni stażu odwiedzaliśmy różne archiwa, centralne i lokalne, poznawaliśmy różnice i podobieństwa w ich funkcjonowaniu, obserwowaliśmy metody pracy i uczyliśmy się od fachowej kadry metod pracy podczas różnego rodzaju warsztatów, dyskusji i prezentacji. Mogliśmy wspólnie dzielić się doświadczeniami naszych krajów. Najciekawsze doświadczenia zdobyłam podczas zajęć w modułach: Narzędzia w zarządzaniu usługami archiwalnymi, gdzie mogłam obserwować, w jaki sposób należy budować pozycję archiwum zakładowego w urzędzie i instytucji, w jaki sposób może ono, wykorzystując nowoczesne narzędzia pracy i innowacyjne rozwiązania techniczne, budować i wdrażać systemy służące do sprawnego zarządzania dokumentacją, wytwarzaną przez aktotwórców i wreszcie, w jaki sposób archiwista zakładowy może i powinien wspierać proces wytwarzania, przechowywania i przekazywania dokumentacji do archiwum.

Z kolei w module Rola archiwisty w społeczeństwie mogłam obserwować, z jakim rozmachem i optymizmem archiwa i biblioteki francuskie wykorzystują siłę mediów społecznościowych, dbając o dobry wizerunek instytucji, nawiązując relacje ze społeczeństwem, a co za tym idzie szeroko pojętą współpracę, chociażby przy projektach indeksacji, które opisałam wyżej.

Odpowiedzialność i ochrona przed ryzykiem to także inspirujący modul, w którym zapoznałam się z procedurą zabezpieczania materiałów archiwalnych 
przed pożarem, procedurą ewakuacji w razie pożaru i obserwowałam ścisłą współpracę archiwów ze strażą pożarną w celu ochrony dóbr narodowych.

$\mathrm{Z}$ kolei w module Budowanie i motywacja zespołu, zainspirowani charyzmą trenera, odkrywaliśmy, jak ważną rolę pełni dobrze dobrany, zorganizowany i doceniany zespół, a zwłaszcza szef-lider.

Podczas zwiedzania poszczególnych instytucji z dużą wnikliwością obserwowałam rozwiązania techniczne, związane z udostępnianiem materiałów archiwalnych w czytelniach, ich wyposażenie, ale i zasady korzystania. Obserwowałam także systemy wystawiennicze wykorzystywane przy organizowaniu wystaw stałych i czasowych, sposoby wykorzystania przestrzeni archiwum do różnorodnych działań. Bardzo interesujące były także rozwiązania systemowe (sygnatury magazynowe, kody kreskowe, kolorowe etykiety, opaski z sygnaturami, etc.) i techniczne wyposażenie magazynów (automatycznie otwierane drzwi i uruchamiane oświetlenie, specjalistyczne wózki, kosze i platformy do przewożenia różnego rodzaju akt, etc.), które ułatwiają pracę z materiałami archiwalnymi, co z całą pewnością warto zaimplementować w polskich archiwach. Warto dodać, że dzięki uprzejmości Ministerstwa Kultury we Francji uczestnicy stażu otrzymali karty upoważniające do nieodpłatnego zwiedzania muzeów państwowych, dzięki czemu mogli skorzystać także z bogatej oferty muzeów w Paryżu. 